\title{
Öğretmenlerin Eğitim İnançlarının Mesleki Yeterlilik Algılarını Yordama Düzeyinin İncelenmesi
}

\section{Investigating the Prediction Level of Teachers' Education Beliefs on Professional Competence Perceptions}

Yazar Bilgileri
Eray Eğmir
Doç. Dr., Afyon Kocatepe
Üniversitesi, Eğitim Fakültesi,
eegmir@aku.edu.tr

\section{Arzu Göres}

Yüksek Lisans Öğrencisi, Afyon Kocatepe Üniversitesi, Eğitim Programları ve Öğretim, arzuydn3@gmail.com

\section{Fatmanur Beycan}

Yüksek Lisans Öğrencisi, Afyon Kocatepe Üniversitesi, Eğitim Programları ve Öğretim,

beycanfatmanur1@gmail.com

\section{Makale Bilgileri}

Anahtar Kelimeler

Eğitim İnançları

Mesleki Yeterlilik Algisı

Eğitim Felsefesi

\section{Keywords}

Educational Beliefs

Perception of Professional

Competence

Educational Philosophy

\section{Makale Geçmişi}

Geliş: 02.03.2021

Düzeltme: 07.04.2021

Kabul: 19.04.2021

\section{Eray Eğmir, Arzu Göres, Fatmanur Beycan}

\section{ÖZ}

Eğitim inancı, eğitim felsefesine dayalı olarak yapılandırılan ve bireyin eğitsel unsurlara dair bakış açısını ortaya koyan bir kavramdır. Bu kavram eğitimin gidişatını belirleyen en önemli faktörlerden biridir ve temelinde eğitim felsefeleri yer almaktadır. Bu bağlamda çalışmada öğretmenlerin eğitim inançları ile mesleki yeterlilik algıları arasındaki ilişkinin incelenmesi amaçlanmıştır. Araştırma sürecinde bu iki olgu cinsiyet, kıdem ve görev yapılan kademe değişkenleri açısından da ele alınmıştır. Yılmaz, Altınkurt ve Çokluk'un (2011) geliştirdikleri eğitim inançları ölçeği ile Schwarzer, Schmitz ve Daytner (1999) tarafından geliştirilen öğretmen öz-yeterlilik algısı ölçeği araştırma sürecinde veri toplamak amacıyla kullanılmıştır. Araştırmanın örneklemini Afyonkarahisar'da görev yapan 279 öğretmen oluşturmaktadır. Yapılan analizler sonucunda öğretmenlerin en çok varoluşçuluk felsefesini benimsediği ortaya çıkmıştır. En az benimsenen felsefi yaklaşım ise esasicilik olmuştur. Yapılan analiz sonuçlarına göre cinsiyet, mesleki kıdem ve görev yapılan kademe değişkenlerine göre anlamlı bir farklılaşma saptanmıştır. Sonuç olarak düşük mesleki kıdeme sahip, temel eğitimde görev alan öğretmenler ile kadın öğretmenlerin çağdaş eğitim felsefelerine yönelimlerinin fazla olduğu görülmüştür. Ayrıca öğretmenlerin eğitim inançları ile mesleki yeterlilik algıları arasında anlamlı ve pozitif bir ilişki olduğu görülmüştür. Çağdaş eğitim felsefelerine yakın olan öğretmenlerin mesleki yeterlilik algılarının yüksek olduğu da saptanmıştır.

\begin{abstract}
Educational belief is a concept that is structured on the basis of educational philosophy and reveals the individual's perspective on educational elements. This concept is one of the most important factors that determine the course of education, and it is based on the educational philosophies adopted. In this study, it was aimed to examine the relationship between teachers' educational beliefs and their perceptions of proficiency. During this review, these two cases were also discussed in terms of variables of gender, seniority, and the level where teachers work. The Scale of Educational Beliefs developed by Yilmaz, Altinkurt, and Çokluk (2011) and the Teacher Self-proficiency Perception Scale developed by Schwarzer, Schmitz, and Daytner (1999) were used to collect data during the research process. The sample of the research consists of 279 teachers working in Afyonkarahisar. As a result of the analysis, it was revealed that teachers adopted the philosophy of existentialism the most. The least adopted philosophical approach has been fundamentalism. According to the results, a significant difference was found according to the gender, seniority, and the level where teachers work variables. As a result, it was observed that female teachers and teachers with low professional seniority and who took part in basic education had a high orientation towards contemporary educational philosophies. In addition, Pearson correlation analysis showed a significant and positive relationship between teachers' educational beliefs and perceptions of professional competence. It has also been determined that teachers who are close to contemporary educational philosophies have a high perception of professional competence.
\end{abstract}




\section{Giriş}

Günümüzde eğitim olgusunu etkileyen en önemli unsurlardan biri felsefedir. Felsefe tanım olarak insanın evren ve insan-evren ilişkisi üzerine sistematik, derinlemesine ve spekülatif (pratikle ilgilenmeksizin sadece bilme ve açıklama amacı güden) düşünmesi sonucu oluşmuş bir bilgi alanıdır (Gutek, 1997). Felsefe pek çok bilimle ilişkilendirilmiş hatta pek çok pozitif bilimin oluşmasına ön ayak olmuştur. Eğitim ile ilişkisi ise yakından ve birbirini tamamlayan bir sarmal şeklindedir. Bunun sebebi hem eğitim ve hem de felsefenin insanı incelemesidir. İnsan, hem felsefe de hem de eğitimde nesne konumundadır. Eğitimde benimsenen felsefeye göre insan değerlendirilir ve şekillendirilir. Eğitimde model alınan felsefe o ülkede yetiştirilmek istenen insan tipine atıfta bulunur; hatta bir ülkenin sadece eğitimine değil siyasetine ve ekonomisine de etki eder. Sönmez (1994) her ekonomik, toplumsal ve siyasal sistemin bir felsefeye dayandığını dile getirir. Eğitim de bu sistemlerden birini oluşturduğu için toplumdaki baskın felsefe, eğitsel anlayış, tercih ve eylemleri de etkiler.

Eğitsel anlayışı oluşturan felsefe, bu sistem içerisinde iş gören tüm paydaşlar için bağlayıcı bir unsur hâline gelmektedir. Eğitim felsefesinin bütünleyici işlevi, pek çok olasılığıın değerlendirilmesi ve analiz edilmesiyle ulaşılan eğitim inançlarını düzenlemek ve birleştirmektir (Brauner ve Burns 1982'den aktaran Altınkurt, Yılmaz ve Oğuz, 2012). Bir eğitim sisteminin işlemesi için paydaşlar içerisindeki en temel bileşenin öğretmenler olduğu ifade edilebilir. Bu nedenle öğretmenlerin davranışları ve bu davranışların altında yatan inanç sistemleri oldukça önemlidir. Bandura'ya (1994) göre davranışların ortaya çıkarken etkilendiği en önemli faktörlerden biri bireyin kabullenmiş olduğu inançlarıdır. Buradan yola çıkarak eğitimin uygulayıcısı olan öğretmenlerin eğitim inançlarının da eğitim uygulamalarına birebir yansıyacağı ön görülmektedir.

Öğretmenlerin eğitsel inanc1, öğrenme-öğretme perspektifi ya da benimsediği felsefe ile ilgilidir (Haney, Czerniak ve Lumpe, 2003'ten aktaran Ayçiçek ve Yelken, 2019). Bu durumda öğretmenler eğitim inançlarını şekillendirirken felsefi yaklaşımlardan etkilenirler; yani bu felsefi yaklaşımlar öğretmenlerin davranışlarının zeminini oluşturur. Bu doğrultuda öğretmenlerin eğitim inançlarını etkileyen en önemli unsur, benimsediği eğitim felsefeleridir (Altınkurt vd., 2012). Eğitim felsefeleri ise ülkelerin siyasi ve ekonomik yaklaşımlarına göre belirlenir ve benimsenir. Ülkelerin benimsemiş olduğu felsefelerin eğitsel süreçteki uygulamalarında öğretmenler hayati öneme sahiptir (Şişman, 2006). Bu nedenle, eğitim sisteminin etkili ve verimli olması için öğretmenlerin ve öğretmen adaylarının eğitim sisteminin dayandığı felsefeye göre yetiştirilmesi gerekmektedir (Sönmez, 1994). Gerçekleştirilen eğitimin yönünü belirleyecek olan, öğretmenlerin sahip oldukları değer yargıları, inanışları ve buna dönük olarak gerçekleştirdikleri uygulamalardır (Eğmir, 2019). Devletinin benimsemiş olduğu felsefeye göre yetişmiş ve bu felsefeyi temel ilke edinmiş öğretmenler, programı o felsefenin amacına uygun ve etkili bir biçimde uygulayabilirler. 
Felsefe, eğitim olgusunu şekillendiren önemli bir araçtır. Öyle ki devletlerin benimsedikleri politikalar felsefeyle şekillenir ve eğitime yansır. Devletlerin nasıl bir insan yetiştirmek istediği, rehber edindiği eğitim felsefeleriyle doğrudan ilişkilidir. Eğitime genel olarak yön veren dört eğitim felsefesi vardır; daimicilik, esasicilik, ilerlemecilik, yeniden kurmacılık. Bu eğitim felsefelerinden daimicilik ve esasicilik geleneksel; ilerlemecilik ve yeniden kurmacılık ise çağdaş eğitim felsefeleri olarak bilinir. Geleneksel eğitim felsefeleri olan daimicilik ve esasicilik uzun yıllar etkisini sürdürmüş ve davranışçı yaklaşım bu iki felsefe ile örtüşmüştür. Tek tek bakılacak olursa daimicilik, terim olarak ebedi, daimi anlamlarına gelir ve daimiciler ebedi doğruların arayışındadır. Bu anlayışta bilginin prensiplerinin tamamen daimi olduğuna inanılır (Tuncel, 2004). Daimicilik, idealizme ve realizme dayanan bir eğitim felsefesi olduğu için aklı temele alır. Bu yüzden aklın geliştirilmesi için entelektüel eğitim verilmesini ister. Aynı zamanda okul, yaşamın kopyası olmalıdır ve insan doğası ve ahlaki ilkeler dünyanın her yerinde aynı olduğu için bunlar öğretilmelidir. Daimicilik felsefesindeki eğitim programında dil, tarih, matematik, sözel sanatlar, felsefe, mantık, doğa bilimleri gibi derslere ağırlık verilmelidir. İdealizmin bir yansıması olarak daimicilikte klasik, kült eserler öğrencilere verilmelidir ki o eserlerden daha önemli bir edebi eser yoktur (Gutek, 1997). Öğrenme-öğretme sürecinde öğretmen bu bilgileri aktaran, öğrenci ise alan konumundadır.

Esasicilik, daimicilik eğitim felsefesine de rehber olan idealizm ve realizm felsefelerinin izlerini taşır. Bu eğitim felsefesi, aklı öne alıp pasif öğrenci profilini savunmuştur. Esasiciler ilerlemecilerin öğrencilerin sosyal problemleriyle ilgilenirken matematik, okuma ve yazma gibi unsurları ihmal ettiklerini savunmuştur. Esasicilere göre öğrencinin problem çözmesine ve derste aktif olmasına gerek yoktur; zaten konu uzmanı öğretmendir (Epçaçan, 2018; Turan, 2016). Bunun yanında okulun ve öğretmenin görevi kültürel aktarım sağlamaktır. Matematik, okuma ve yazma temel becerilerinin yanında eğitim programında yabancı dil, tarih ve fen bilimleri de olmalıdır. Esasicilere göre tarihin süzgecinden geçen bilgiler, öğrencilerin yaşayarak öğrendikleri bilgilere oranla daha önemlidir. Bu yüzden geçmişin süzgecinden geçen bilgilere yenileri eklenerek yani geleceğin de etkisi katılarak öğrencilere verilmelidir. Daimicilik ve esasiciliği ayıran önemli nokta ise budur; daimiciler geçmişe sıkı sıkıya bağlı iken esasiciler geleceği de göz önüne alır (Epçaçan, 2018). Program tasarısı yapılırken konu alanı yaklaşımı bu felsefi anlayışa göre belirlenmelidir.

Günümüzde geleneksel eğitim felsefeleri her ne kadar kullanılmasa da etkilerinin hâlâ devam ettiğini söylemek yanlış olmaz. Ülkemizde 2005 yılında programların revize edilmesiyle davranışçı yaklaşımdan yapılandırmacı yaklaşıma geçilmiştir. Yapılandırmacı yaklaşımın temelinde ilerlemeci ve yeniden kurmacı eğitim felsefelerinin olduğunu söylenebilir. İlerlemeci ve yeniden kurmacı eğitim felsefeleri çağdaş eğitim felsefeleri olarak sınıflandırılabilir. İlerlemecilik 1930'larda ortaya çımış pragmatik felsefeye dayanan bir eğitim anlayışıdır. Bu anlayışa göre öğretmen rehber, öğrenci ise 
keşfeden öğrenen konumundadır. Bilginin yeniden öğrenci tarafından keşfedilmesi bilginin mutlak olmadığının bir göstergesidir. İlerlemeci anlayışa göre okul yaşamın kopyası değil kendisidir. Bu da öğrencilerin sosyal problemlerinin de okul içerisinde ele alınabileceği görüşünü desteklemektedir. Konular ve dersler öğretmene göre değil öğrenciye göre düzenlenmelidir. Bu anlayışa göre eğitim kurama değil uygulamaya dönük olmalıdır; bu yüzden sınama durumlarında ezbere yer verilmemelidir. Öğrenme yaşantı yoluyla ve doğal ortamında gerçekleşir (Epçaçan, 2018; Erişen, 2019; Turan, 2016).

Yeniden kurmacılık eğitim felsefesi ise Avrupa'da ortaya çıkmış bir bunalım, çöküntü felsefesidir. Temelinde pragmatizm ve varoluş̧̧u felsefe vardır. Gelişimin ve değişimin ancak toplumsal reformla olabileceğini savunurlar. Bu anlayışa göre toplumsal sorunlar okula hatta ders ortamına getirilmelidir. Öğrenciler bu sorunların bilincinde olup çözümü için sağduyu ile yaklaşmalıdır. Öğretmen ise bu sorunları sınıfa taşıyan rehberdir. Öğrenciler için toplum bir laboratuvar gibidir ve öğrenciler, içerisinde bulundukları toplumun sorunlarına duyarlı olmalıdır. Sorunların çözümü için sınıf demokratik bir ortam hâline getirilmelidir. Sönmez'e (1994) göre yeniden kurmacılıkta sadece yaşanılan an değil gelecek de oldukça önemlidir. Eğitimin görevi ise toplumu yeniden inşa etmek ve düzenlemektir. Sınıfta yeni öğretim yöntem ve teknikleri kullanılırken sınama durumları ise ezberden çok öğrencinin bilimsel yöntemi ve eleştirel düşünmeyi kullanılıp kullanmadığını ölçecek şekilde olmalıdır. Öncü olan öğretmen sınıf içerisinde ceza vermekten kaçınmalıdır (Epçaçan, 2018; Turan, 2016).

\section{Öğretmenlerin Mesleki Yeterlilik Algıları}

Dünya bir değişim ve gelişim döngüsü içerisinde geçmişten günümüze her alanda farklılaşarak bugüne gelmiştir. 21. yüzyılın bilgi ve teknoloji çağı olarak anılması bu değişimin ve gelişimin göstergesidir. Toplumun gelişmeye en az direnç gösteren olgusu eğitimdir. Zira siyasetçiler toplumu değiştirmek için en önce eğitim kanalını kullanmaktadır. Eğitimin de değişimi uygulayan en önemli bileşeni tabii ki öğretmenlerdir. Öğretmenler, değişimi ve gelişimi benimsemesi ve yansıtması gereken en önemli meslek grubudur. Gelişen dünya ve teknoloji şartlarına göre öğretmenlerden beklenen nitelikler artmış ve değişim de göstermiştir. Karacaoğlu'na (2008) göre öğretmenlerin niteliği öğrencilerin niteliğini de doğrudan etkilemektedir. Buna ek olarak öğretmenler ayna görevi görerek öğrencilerini dolayısıyla toplumu kendi nitelikleri doğrultusunda yetiştirmektedir.

Sarp-Astan'a (2017) göre öğretmenlerin niteliğinin artması öz yeterlilik algılarına ve mesleki yeterliliklerine bağlıdır. Bandura (1994) yeterlilik algılarının bireylerin bilgi, beceri ve deneyimleriyle oluştuğunu ifade etmiştir. Bu yönüyle öz yeterlilik ve mesleki yeterlilik algıları öğretmenlerin öğrenme-öğretme süreçlerindeki deneyimleri sonucu oluşur. Buna ek olarak Avcı-Akçalı (2016) öğretmen adaylarının uygulamalı dersler aracılığıyla deneyim kazandırılarak öz yeterlilik algılarının 
ve mesleki yeterlilik algılarının geliştirilmesi gerektiğini ifade etmiştir. Yani öğretmen adaylarının meslek yaşamlarına uyum sağlamaları ve mesleki yönden yetersiz hissetmemeleri için formasyon eğitiminde uygulamalı dersler aracılığıyla deneyim kazandırılmalıdır. Bütün bunların yanında öğretmenlerden beklenen yeterlilik düzeyleri değişmekte, Milli Eğitim Bakanlığı (MEB) öğretmenlerin pek çok farklı alanda yeterli olmalarını beklemektedir. Bu durum öğretmenlerin iş yükünü ve mesleki yıpranma düzeylerini arttırmaktadır. Karacaoğlu (2008) öğretmenlerin yeterlilik algılarını incelediği çalışmasında öğretmenlerin bilimsel çalışmaları takip etme, teknolojik olarak donanımlı olma, analitik olma, güncel bilgilerden haberdar olma gibi pek çok alanda kendilerini yetersiz hissettiklerini ifade etmiştir. Bu durumun öğretmenlerin kalitesini ve öğretimin niteliğini azalttığını söylemek yanlış olmaz.

$\mathrm{Bu}$ çalışma için alanyazın tarandığında öğretmenlerin eğitim inançları ile mesleki yeterlilik algıları arasında bir ilişkinin var olup olmadığını araştıran bir çalışmaya rastlanmamıştır. Ayrıca öğretmenlerin eğitim inançlarının mesleki yeterlilikleri üzerindeki etkisini ortaya çıkarmak amacıyla bu çalışma yürütülmüştür.

\section{Araştırmanın Önemi}

Geçmişten günümüze eğitim felsefeleri eğitimi yönlendiren, şekillendiren en önemli olgular olarak karşımıza çıkmıştır. Eğitim felsefeleri, devletlerin sahip olduğu misyonlara eş değer olarak o devletin eğitimine yön vermiştir. Eğitimin en önemli unsuru olan öğretmenler ise gerek yetiştirilirken gerekse meslek hayatına geçiş yaptıklarında belli eğitim felsefeleri edinmiş ve bunlara uygun olarak eğitim vermeye çalışmışlardır. Bu yüzden öğretmenlerin hangi eğitim felsefesine yakın olduğunu anlamak öğrencilerin nasıl eğitim aldığını anlamak için ön koşuldur.

Öğretmenlerin sahip olduğu eğitim inançlarını etkileyen bazı unsurlar vardır. Bunlardan, mesleki yeterlilik algısının eğitim felsefeleri üzerindeki etkisi yadsınamaz. Bu yüzden bu çalışma öğretmenlerin eğitim inançlarıyla mesleki yeterlilik algıları arasında ilişkinin var olup olmadığının incelenmesi, ilişki varsa bunun ne düzeyde olduğunun tespit edilmesi açısından önemlidir. Bununa birlikte alanyazın incelendiğinde öğretmenlerin eğitim inançlarını ve mesleki yeterlilik algılarını inceleyen çalışmaların, bu çalışmanın içeriğinden farklı olduğu görülmüştür. Bu çalışmalar üç grupta toplanmıştır: Öğretmenlerin ve öğretmen adaylarının eğitim inançlarına ilişkin görüşlerinin incelendiği çalışmalar (Çelik ve Orçan, 2016; Uğurlu ve Çalmaşur, 2017; Yılmaz ve Tosun, 2013), çeşitli değişkenlere göre öğretmenlerin eğitim inançlarını inceleyen çalışmalar (Aslan, 2017; Çapri ve Çelikkaleli, 2008; Yaralı, 2020) ve öğretmenlerin eğitim inançları ile başka olgular arasındaki ilişkiyi inceleyen çalışmalardır (Balcı ve Küçükoğlu, 2019; Baş, 2015; Tunca, Alkın-Şahin ve Oğuz, 2015). Bu çalışma, öğretmenlerin eğitim inançları ile mesleki yeterlilikleri arasındaki ilişkiyi belirlemek ve bu konuda alanyazındaki boşluğu doldurmak için yapılmıştır. Okullarda verilen eğitimin kalitesinin 
yüksek olması öğretmenlere bağlıdır. Kaliteli bir eğitim-öğretim süreci ise öğretmenlerin kendini mesleki olarak yeterli hissetmesiyle oluşur. Bu yüzden öğretmenlerin mesleki yeterlilik algılarının ne düzeyde olduğunun ve bunu etkileyen eğitim felsefelerinin araştırılmasının alanyazına önemli bir katkı sağlayacağı düşünülmektedir.

\section{Problem Durumu}

Bu bilgiler 1şı̆̆ında araştırmada ilk olarak öğretmenlerin baskın eğitim inançlarının ne olduğu ve mesleki yeterlilik algılarının ne düzeyde olduğu tespit edilmeye çalışılmıştır. Bunun ardından çalışmada ikinci olarak öğretmenlerin eğitim inançları ve mesleki yeterlilik algılarının cinsiyet, mesleki kıdem ve görev yapılan kademe değişkenlerine göre anlamlı olarak farklılaşıp farklılaşmadığını belirlemek amaçlanmıştır. Araştırmada son olarak öğretmenlerin eğitim inançları ile mesleki yeterlilik algıları arasında anlamlı bir ilişkinin var olup olmadığı ve öğretmenlerin eğitim inançlarının mesleki yeterlilik algılarını ne düzeyde yordadığı araştırılmıştır.

\section{Yöntem}

Çalışma ilişkisel (korelasyonel) araştırma modeline göre tasarlanmıştır. İlişkisel tarama modelleri, genellikle daha karmaşık özellikteki faktörlerin daha iyi anlaşılabilmesi için yaklaşık aynı zamanda aynı bireylerden elde edilen farklı değişkenler arasındaki ilişkileri inceler. Araştırmacı, var olan ilişkileri bulmak ve tanımlamak için olguları değiştirmeye çalışmadan araştırmasını yürütür (Mertens, 2015). Ayrıca, ilişkisel araştırma, bir ilişki hakkında daha üst düzey araştırma yapmak için gerekli ipuçlarını sağlar (Büyüköztürk, Kılıç-Çakmak, Akgün, Karadeniz ve Demirel, 2013, s. 185). Bu çalışma Afyonkarahisar ilinde farklı kademelerde görev yapmakta olan öğretmenlerden toplanan veriler aracıllı̆ıyla öğretmenlerin eğitim inançları ile mesleki yeterlilik algıları arasındaki ilişkiyi belirlemeyi amaçlamıştır. Buna ek olarak, öğretmenlerin eğitim inançlarının mesleki yeterlilik algılarını ne düzeyde yordadığı da çalışmada incelenmiştir. Öğretmenlerin eğitim inançları ile mesleki yeterlilik algılarının cinsiyet, mesleki kıdem ve görev yapılan kademe değişkenlerine göre anlamlı farklılık gösterip göstermediğini belirlemek de çalı̧̧manın alt problemleri arasındadır.

\section{Evren ve Örneklem}

Araştırmanın evrenini Afyonkarahisar ilinde görev yapmakta olan öğretmenler oluşturmaktadır ( $\mathrm{N}=8.713$ ). Araştırmanın veri toplama araçları, örneklemi oluşturan Afyonkarahisar ilinde farklı kademelerde görev yapmakta olan ve uygun örnekleme yöntemi ile belirlenmiş 279 öğretmene uygulanmıştır. Uygun örnekleme yöntemi, zaman, para ve işgücü açısından var olan sınırlılıklar nedeniyle örneklemin kolay ulaşılabilir ve uygulama yapılabilir birimlerden seçilmesidir (Büyüköztürk, 2014). Bu örneklem belirleme metodu araştırmacının yakın ve erişilmesi kolay olan bir durumu seçmesi nedeniyle araştırmaya hız kazandıran bir yöntemdir. Bu yöntemde yanlılık fazladır; çünkü herhangi bir birimin örneğe seçilme olasılığı bilinmez (Dawson ve Trapp, 2001'den aktaran 
Kılıç, 2013). Bu çalışmada örneklem sayısı ölçeğin madde sayısının beş katından fazla olacak şekilde belirlenmiştir (Büyüköztürk, 2014). Araştırmada kısa zamanda yeterli sayıda veri toplanması amacıyla bu yöntem tercih edilmiştir. Bu çalışmanın etik açıdan bir sakınca taşımadığı Afyon Kocatepe Üniversitesi Sosyal ve Beşeri Bilimler Bilimsel Araştırma ve Yayın Etiği Kurulunun almış olduğu 22.01.2021 tarih ve 2021/38 sayılı karar ile tespit edilmiştir. Örneklemin değişkenlere göre dağılımı Tablo 1'de sunulmaktadır.

Tablo 1. Örneklemin Değişkenlere Göre Dağılımı

\begin{tabular}{|c|c|c|c|}
\hline Değişken & Değer & $f$ & $\%$ \\
\hline \multirow{2}{*}{ Cinsiyet } & Kadın & 171 & 61,3 \\
\hline & Erkek & 108 & 38,7 \\
\hline \multirow{4}{*}{ Mesleki Kıdem } & $1-5$ yıl & 78 & 28,0 \\
\hline & 6-10 yil & 77 & 27,6 \\
\hline & $11-16$ y1l & 38 & 13,6 \\
\hline & 16 yıl ve üzeri & 86 & 30,8 \\
\hline \multirow{4}{*}{ Kademe } & Okul öncesi & 13 & 4,7 \\
\hline & İlkokul & 65 & 23,3 \\
\hline & Ortaokul & 132 & 47,3 \\
\hline & Ortaöğretim & 89 & 24,7 \\
\hline Toplam & & 279 & 100 \\
\hline
\end{tabular}

\section{Veri Toplama Araçları}

Araştırmanın, veri toplama sürecinde öğretmenlerin hangi eğitim felsefesini kavramsallaştırdıklarını belirlemek amacıyla "Eğitim İnançları Ölçeği", öğretmenlerin öz-yeterlilik algısını ölçmek amacıyla ise “Öğretmen Öz-Yeterlilik Algısı Ölçeği” kullanılmıştır.

\section{Eğitim İnançları Ölçeği (EİÖ):}

Yılmaz, Altınkurt ve Çokluk (2011) tarafından geliştirilen EIÖ, 40 maddeden oluşan beşli likert türünde bir ölçektir. Ölçek "İlerlemecilik”, “Varoluşçuluk”, “Yeniden Kurmacılık”, “Daimicilik” ve "Esasicilik" olmak üzere 5 alt boyuttan oluşmaktadır. Ölçeğin güvenirliğini belirlemek amacıyla yapılan analizde, Eğitim İnançları Ölçeği'nin alt boyutlarının Cronbach Alpha iç tutarlılık katsayılarının .70 ve .91 arasında değiştiği belirlenmiştir. Bu çalışmada da Cronbach Alpha iç tutarlılık katsayılarının .78 ile .80 arasında değiştiği görülmüştür. Bu değerlere göre ölçeğin yüksek güvenilirliğe sahip olduğu görülmektedir (Tavşancıl, 2006, s. 29).

\section{Öğretmen Öz-Yeterlilik Algısı Ölçeği (ÖÖYA):}

Araştırmada ayrıca, Schwarzer, Schmitz ve Daytner (1999) tarafından Bandura'nın Kuramı temel alınarak geliştirilmiş olan "Öğretmen öz-yeterlilik algısı ölçeği” kullanılmıştır. Ölçek 10 maddeden oluşan dörtlü likert türünde bir ölçektir. Ölçekteki derecelendirme ‘hiç doğru değil', ‘biraz doğru', 'kısmen doğru' ve 'tamamen doğru' şeklindedir. Ölçeğin Cronbach Alpha iç tutarlılık katsayısı .79 olarak bulunmuştur. Bu çalışmada ise bu değer .87 olarak bulunmuştur. Bu değere göre ölçeğin yüksek güvenilirliğe sahip olduğu görülmektedir (Tavşancıl, 2006, s. 29). 


\section{Verilerin Analizi}

Ölçeklerden elde edilen veriler istatistik programı kullanılarak analiz edilmiştir. Öğretmenlerin eğitim inançları ve mesleki yeterlilik algı düzeylerini belirlemek amacıyla, katılımcıların ölçeğe verdikleri cevapların ortalamaları alınmıştır. Sonrasında normallik testleri yapılmış ve eğitim inançları ve mesleki yeterlilik algılarına ilişkin elde edilen verinin normal dağıldığı belirlenmiştir. Bu doğrultuda şu analizler yapılmıştır:

- Öğretmenlerin eğitim inançlarının ve mesleki yeterlilik algı düzeylerinin cinsiyet değişkenine göre anlamlı farklılık gösterme durumunu incelemek amacıyla bağımsız gruplar t-testi;

- Öğretmenlerin eğitim inançlarının ve mesleki yeterlilik algı düzeylerinin mesleki kıdem ve görev yapılan kademe değişkenlerine göre anlamlı farklılık gösterme durumunu incelemek amacıyla tek yönlü ANOVA;

- Öğretmenlerin eğitim inançları ve mesleki yeterlilik algı düzeyleri arasında anlamlı bir ilişki bulunup bulunmadı ̆̆ını belirlemek amacıyla Pearson korelasyon analizi;

- Öğretmenlerin eğitimi inançlarının mesleki yeterlilik algılarını ne düzeyde yordadığını belirlemek amacıyla çoklu doğrusal regresyon testi yapılmıştır.

\section{Bulgular}

Araştırmanın ilk probleminde eğitim inançları ve mesleki yeterlilik algı düzeylerini belirlemek amacıyla, öğretmenlerin ölçeğe verdikleri cevapların ortalamaları incelenmiştir. Bu doğrultuda elde edilen veriler Tablo 2' de sunulmaktadır.

Tablo 2. Ölçekler ve Alt Boyutlarına İliş̧kin Betimsel İstatistikler

\begin{tabular}{lccccc}
\hline Boyut & $f$ & Min. & Maks. & $\bar{x}$ & Ss \\
\hline İlerlemecilik & 279 & 42,00 & 65,00 & 4,46 & 5,16 \\
\hline Varoluşçuluk & 279 & 20,00 & 35,00 & 4,69 & 2,74 \\
\hline Yeniden Kurmacilık & 279 & 11,00 & 35,00 & 4,15 & 4,23 \\
\hline Daimicilik & 279 & 11,00 & 40,00 & 4,19 & 4,80 \\
\hline Esasicilik & 279 & 5,00 & 25,00 & 2,74 & 4,56 \\
\hline Mesleki Yet. Algisı & 279 & 18,00 & 50,00 & 3,48 & 5,37 \\
\hline
\end{tabular}

Tablo 2'deki veriler incelendiğinde öğretmenlerin en baskın eğitim inancının "varoluşçuluk" olduğu görülmektedir. Bununla birlikte öğretmenler ilerlemecilik eğitim inancına "tamamen katılıyorum" düzeyinde, yeniden kurmacılık ve daimicilik inançlarına "katılıyorum" düzeyinde ve esasicilik inancına ise "kararsızım" düzeyinde katılım göstermişlerdir. Esasicilik eğitim inancına dair ölçek maddelerinin öğretmen otoritesi ve cezaya ilişkin atıflar içermesinin bu durumu ortaya çıkardığ ifade edilebilir. Daimicilik eğitim inancı da geleneksel ve tutucu bir inanç olmasına karşın, bu inanca dair ölçek maddelerinin karakter gelişimi, değerler eğitimi ve entelektüel beceriye vurgu yapması, bu 
ölçeğe dair ortalamanın yüksek çıkması durumunu ortaya çıkarmıştır. Bu bağlamda, öğretmenlerin esasicilik eğitim inancı dışında diğer inanç boyutlarında yüksek bir düzeye sahip olduğu belirtilebilir.

Öğretmenlerin baskın eğitim inançları incelendiğinde, çoğunluğun varoluşçuluk eğitimi inancına katılım gösterdiği belirlenmiştir ( $\mathrm{f}=211)$. Bu eğitim inancını sırasıyla daimicilik ( $\mathrm{f}=54)$, yeniden kurmacılık ( $f=46)$, ilerlemecilik $(f=45)$ ve esasicilik ( $f=6)$ eğitimi inancı izlemektedir. Ayrıca, öğretmenlerin mesleki yeterlilik algıları ölçeğine verdikleri cevapların aritmetik ortalaması 3,48 olarak bulunmuştur. Buna dayalı olarak öğretmenlerin yüksek düzeyde bir mesleki yeterlilik algısına sahip oldukları ifade edilebilir.

Araştırmanın ikinci probleminde öğretmenlerin eğitim inançları ve mesleki yeterlilik algılarının cinsiyet, mesleki kıdem ve görev yapılan kademe değişkenlerine göre anlamlı olarak farklılaşıp farklılaşmadığı incelenmiştir. İlk olarak cinsiyet değişkenine ilişkin sonuçlar Tablo 3’te verilmiştir.

Tablo 3. Eğitim İnançları ve Mesleki Yeterlilik Algılarının Cinsiyet Değişkenine Göre Farklılaşma

Durumu

\begin{tabular}{|c|c|c|c|c|c|c|}
\hline Boyut & Cinsiyet & $f$ & Art. Ort. & Std. Sapma & $t$ & $p$ \\
\hline \multirow{2}{*}{ İlerlemecilik } & Kadın & 171 & 58,72 & 4,63 & \multirow{2}{*}{2,692} & \multirow{2}{*}{$.00^{*}$} \\
\hline & Erkek & 108 & 56,95 & 5,76 & & \\
\hline \multirow{2}{*}{ Varoluşçuluk } & Kadın & 171 & 33,36 & 2,44 & \multirow{2}{*}{3,475} & \multirow{2}{*}{$.00^{*}$} \\
\hline & Erkek & 108 & 32,15 & 3,03 & & \\
\hline \multirow{2}{*}{ Yeniden Kurmacılık } & Kadın & 171 & 29,77 & 3,78 & \multirow{2}{*}{3,473} & \multirow{2}{*}{$.00^{*}$} \\
\hline & Erkek & 108 & 28,00 & 4,67 & & \\
\hline \multirow{2}{*}{ Daimicilik } & Kadın & 171 & 33,60 & 4,58 & \multirow{2}{*}{ 298 } & \multirow{2}{*}{.76} \\
\hline & Erkek & 108 & 33,42 & 5,15 & & \\
\hline \multirow{2}{*}{ Esasicilik } & Kadın & 171 & 12,91 & 4,49 & \multirow{2}{*}{$-3,861$} & \multirow{2}{*}{$.00^{*}$} \\
\hline & Erkek & 108 & 15,02 & 4,39 & & \\
\hline \multirow{2}{*}{ Mesleki Yet. Algısı } & Kadın & 171 & 42,19 & 4,98 & \multirow{2}{*}{1,459} & \multirow{2}{*}{.14} \\
\hline & Erkek & 108 & 41,23 & 5,90 & & \\
\hline
\end{tabular}

Tablo 3'teki veriler incelendiğinde öğretmenlerin daimicilik eğitim inancı dışındaki tüm eğitim inançları cinsiyet değişkenine göre anlamlı farklılık göstermektedir. Buna karşın öğretmenlerin mesleki yeterlilik algılarının cinsiyet değişkenine anlamlı farklılık göstermediği görülmektedir. Elde edilen farkların esasicilik eğitim inancı dışında kadın öğretmenler lehine bulunduğu ifade edilebilir. Başka bir deyişle, erkek öğretmenler esasici anlayışa kadın öğretmenlerden daha fazla katılım göstermektedir. Kadın öğretmenlerin mesleki yeterlilik algıları erkek öğretmenlerden daha yüksek düzeyde olmasına rağmen bu farklılık anlamlı değildir.

Bunun ardından öğretmenlerin eğitim inançları ve mesleki yeterlilik algılarının mesleki kıdem değişkenine göre anlamlı olarak farklılaşıp farklılaşmadığı incelenmiştir. Gerçekleştirilen tek yönlü ANOVA testine dair bulgular Tablo 4'te verilmiştir. 
Tablo 4. Eğitim İnançları ve Mesleki Yeterlilik Algılarının Mesleki Kıdem Değişkenine Göre Farklılaşma Durumu

\begin{tabular}{|c|c|c|c|c|c|c|c|}
\hline Boyut & Kıdem & $f$ & Art. Ort. & $F$ & $s d$ & $p$ & $\begin{array}{l}\text { Farkın } \\
\text { Kaynă̆ı }\end{array}$ \\
\hline \multirow{4}{*}{ İlerlemecilik } & $1-5$ y1l & 78 & 58,12 & \multirow{4}{*}{2,746} & \multirow{4}{*}{3} & \multirow{4}{*}{$.04^{*}$} & \multirow{4}{*}{$2-4 ; 3-4$} \\
\hline & 6-10 yil & 77 & 58,81 & & & & \\
\hline & 11-16 y1l & 38 & 59,05 & & & & \\
\hline & 16 yıl ve üzeri & 86 & 56,81 & & & & \\
\hline \multirow{4}{*}{ Varoluşçuluk } & $1-5$ yil & 78 & 33,30 & \multirow{4}{*}{5,082} & \multirow{4}{*}{3} & \multirow{4}{*}{$.00^{*}$} & \multirow{4}{*}{$1-4 ; 3-4$} \\
\hline & 6-10 yil & 77 & 33,15 & & & & \\
\hline & $11-16$ yıl & 38 & 33,60 & & & & \\
\hline & 16 yıl ve üzeri & 86 & 31,97 & & & & \\
\hline \multirow{4}{*}{ Yeniden Kurmacılık } & $1-5$ yil & 78 & 29,33 & \multirow{4}{*}{,387 } & \multirow{4}{*}{3} & \multirow{4}{*}{.76} & \\
\hline & 6-10 yıl & 77 & 29,25 & & & & \\
\hline & $11-16$ y1l & 38 & 29,13 & & & & \\
\hline & 16 yıl ve üzeri & 86 & 28,68 & & & & \\
\hline \multirow{4}{*}{ Daimicilik } & $1-5$ yil & 78 & 32,29 & \multirow{4}{*}{3,241} & \multirow{4}{*}{3} & \multirow{4}{*}{$.02^{*}$} & \multirow{4}{*}{$4-1$} \\
\hline & 6-10 yıl & 77 & 33,51 & & & & \\
\hline & $11-16$ yil & 38 & 33,68 & & & & \\
\hline & 16 yıl ve üzeri & 86 & 34,60 & & & & \\
\hline \multirow{4}{*}{ Esasicilik } & $1-5$ yıl & 78 & 12,26 & \multirow{4}{*}{8,464} & \multirow{4}{*}{3} & \multirow{4}{*}{$.00^{*}$} & \multirow{4}{*}{$\begin{array}{l}3-1 ; 4-1 \\
4-2\end{array}$} \\
\hline & $6-10$ yil & 77 & 13,03 & & & & \\
\hline & $11-16$ yıl & 38 & 14,02 & & & & \\
\hline & 16 yıl ve üzeri & 86 & 15,54 & & & & \\
\hline \multirow{4}{*}{ Mesleki Yet. Algısı } & $1-5$ yil & 78 & 43,12 & \multirow{4}{*}{2,706} & \multirow{4}{*}{3} & \multirow{4}{*}{$.04^{*}$} & \multirow{4}{*}{$1-2$} \\
\hline & 6-10 y1l & 77 & 40,71 & & & & \\
\hline & $11-16$ yıl & 38 & 41,63 & & & & \\
\hline & 16 yıl ve üzeri & 86 & 41,70 & & & & \\
\hline
\end{tabular}

Tablo 4'teki veriler incelendiğinde öğretmenlerin yeniden kurmacılık eğitim inancı dışında tüm eğitim inançlarının ve mesleki yeterlilik algılarının mesleki kıdem değişkenine göre anlamlı farklılaştığı belirlenmiştir. Analize ilişkin bulgulara göre öğretmenlerin çağdaş eğitim inançlarının kıdemi daha düşük öğretmenler lehine, geleneksel eğitim inançlarının ise kıdemi yüksek öğretmenler lehine farklılaştı̆̆ı söylenebilir. Öğretmenlerin mesleki yeterlilik algılarına bakıldığında mesleki kıdemi 1-5 yıl olan öğretmenler ile 6-10 yıl olan öğretmenler arasında, 1-5 yıl kıdeme sahip öğretmenler lehine bir farklılığın olduğu görülmektedir.

Bunun ardından öğretmenlerin eğitim inançları ve mesleki yeterlilik algılarının görev yapılan kademe değişkenine göre anlamlı olarak farklılaşıp farklılaşmadığı incelenmiştir. Gerçekleştirilen tek yönlü ANOVA testine dair bulgular Tablo 5'te verilmiştir.

Tablo 5. Eğitim İnançları ve Mesleki Yeterlilik Algılarının Kademe Değişkenine Göre Farklılaşma Durumu

\begin{tabular}{|c|c|c|c|c|c|c|c|}
\hline Boyut & Kademe & $f$ & Art. Ort. & $F$ & $s d$ & $p$ & $\begin{array}{l}\text { Farkın } \\
\text { Kaynă̆ı }\end{array}$ \\
\hline \multirow{4}{*}{ İlerlemecilik } & Okul öncesi & 13 & 59,92 & \multirow{4}{*}{2,295} & \multirow{4}{*}{3} & \multirow{4}{*}{.07} & \\
\hline & İlkokul & 65 & 58,18 & & & & \\
\hline & Ortaokul & 132 & 58,44 & & & & \\
\hline & Ortaöğretim & 89 & 56,76 & & & & \\
\hline
\end{tabular}




\begin{tabular}{|c|c|c|c|c|c|c|c|}
\hline \multirow{4}{*}{ Varoluşçuluk } & Okul öncesi & 13 & 33,15 & \multirow{4}{*}{1,171} & \multirow{4}{*}{3} & \multirow{4}{*}{.32} & \\
\hline & İlkokul & 65 & 33,01 & & & & \\
\hline & Ortaokul & 132 & 33,09 & & & & \\
\hline & Ortaöğretim & 89 & 32,36 & & & & \\
\hline \multirow{4}{*}{ Yeniden Kurmacılık } & Okul öncesi & 13 & 30,84 & \multirow{4}{*}{1,682} & \multirow{4}{*}{3} & \multirow{4}{*}{.17} & \\
\hline & İlkokul & 65 & 29,32 & & & & \\
\hline & Ortaokul & 132 & 29,21 & & & & \\
\hline & Ortaöğretim & 89 & 28,28 & & & & \\
\hline \multirow{4}{*}{ Daimicilik } & Okul öncesi & 13 & 36,30 & \multirow{4}{*}{1,670} & \multirow{4}{*}{3} & \multirow{4}{*}{.17} & \\
\hline & İlkokul & 65 & 33,30 & & & & \\
\hline & Ortaokul & 132 & 33,27 & & & & \\
\hline & Ortaöğretim & 89 & 33,72 & & & & \\
\hline \multirow{4}{*}{ Esasicilik } & Okul öncesi & 13 & 13,15 & \multirow{4}{*}{3,971} & \multirow{4}{*}{3} & \multirow{4}{*}{$.00^{*}$} & \multirow{4}{*}{$4-3 ; 4-2$} \\
\hline & İlkokul & 65 & 13,44 & & & & \\
\hline & Ortaokul & 132 & 13,09 & & & & \\
\hline & Ortaöğretim & 89 & 15,33 & & & & \\
\hline \multirow{4}{*}{ Mesleki Yet. Algısı } & Okul öncesi & 13 & 41,53 & \multirow{4}{*}{ 110, } & \multirow{4}{*}{3} & \multirow{4}{*}{.95} & \\
\hline & İlkokul & 65 & 41,98 & & & & \\
\hline & Ortaokul & 132 & 41,91 & & & & \\
\hline & Ortaöğretim & 89 & 41,53 & & & & \\
\hline
\end{tabular}

Tablo 5'teki veriler incelendiğinde öğretmenlerin esasicilik eğitim inançlarının görev yapılan kademe değişkenine göre anlamlı olarak farklılaşttğı belirlenmiştir. Belirlenen bu farkın ortaöğretim kademesinde görev yapan öğretmenler ile ilkokul ve ortaokulda görev yapan öğretmenler arasında, ortaöğretim kademesinde görev yapan öğretmenler lehine olduğu belirlenmiştir. Diğer inanç boyutlarında görev yapılan kademe yükseldikçe geleneksel eğitim inançlarında ortalamalar artmakta, çağdaş eğitim inançlarında ise azalmaktadır. Bu durumun kademelerdeki öğretime ilişkin eğitim felsefesini yansıttığı söylenebilir. Okul öncesi ve ilkokul kademelerinde çağdaş inançlara ilişkin uygulamaların daha yaygın olması, bunun aksine ortaöğretim kademesinde disiplin tasarımı nedeniyle bilgi aktarım ve öğretim süreçlerine odaklanılması yani geleneksel inançların baskın oluşu bu durumu ortaya çıkarmış olabilir. Mesleki yeterlilik algısı incelendiğinde ise en yüksek algı düzeyinin ilkokul ve ortaokul öğretmenlerinde bulunduğu ancak bu farklılığın anlamlı olmadığı görülmektedir.

Çalışmada ayrıca öğretmenlerin eğitim inançları ile mesleki yeterlilik algıları arasında anlamlı bir ilişki bulunup bulunmadığı incelenmiştir. Bu doğrultuda yapılan Pearson korelasyon analizine ilişkin bulgular Tablo 6'da verilmiştir.

Tablo 6. Eğitim İnançları ve Mesleki Yeterlilik Algıları Arasındaki İlişki

\begin{tabular}{|c|c|c|c|c|c|c|}
\hline & 1 & 2 & 3 & 4 & 5 & 6 \\
\hline 1. Mesleki Yet. Alg1sı & 1,00 & & & & & \\
\hline 2. İlerlemecilik & $428^{* *}$ & 1,00 & & & & \\
\hline 3. Varoluşçuluk & , 380** &, $729^{* *}$ & 1,00 & & & \\
\hline 4. Yeniden Kurmacilık & $345^{* *}$ &, $585^{* *}$ &, $518^{* *}$ & 1,00 & & \\
\hline 5. Daimicilik & ,202** & $297^{* *}$ & $256^{* *}$ & $497^{* *}$ & 1,00 & \\
\hline 6. Esasicilik &,$- 052^{* *}$ &,$- 311^{* *}$ &,$- 252^{*}$ &,$- 026^{* *}$ & $293^{* *}$ & 1,00 \\
\hline
\end{tabular}


Tablo 6'daki veriler incelendiğinde öğretmenlerin esasicilik eğitim inancı dişında eğitim inançları ve mesleki yeterlilik algıları arasında pozitif ve anlamlı ilişkiler mevcuttur. Mesleki yeterlilik algısı ile en yüksek ilişki düzeyine sahip eğitim inancı ilerlemecilik olurken $(r=.428 ; p<.01)$ en düşük ilişki düzeyine sahip eğitim inancı ise esasicilik olarak belirlenmiştir $(r=-.052 ; p<.01)$. Tüm ilişki değerleri anlamlı bulunmuştur.

Bunun ardından öğretmenlerin eğitim inançlarının mesleki yeterlilik algılarını ne düzeyde yordadığını belirlemek amacıyla çoklu doğrusal regresyon analizi gerçekleştirilmiştir. Regresyon analizinin bulguları Tablo 7'de sunulmuştur.

Tablo 7. Öğretmenlerin Mesleki Yeterlilik Algılarının Yordanmasına İlişkin Varyans Analizi Sonuçları

\begin{tabular}{ccccccc}
\hline Model & $\begin{array}{c}\text { Kareler } \\
\text { Toplamı }\end{array}$ & sd & $\begin{array}{c}\text { Kareler } \\
\text { Ortalamasi }\end{array}$ & $\boldsymbol{F}$ & $\boldsymbol{p}$ \\
\hline Regresyon & 1639,655 & 4 & 409,914 & \multirow{2}{*}{17,595} & \multirow{2}{*}{, $00^{*}$} \\
\hline Hata & 6383,385 & 274 & 23,297 & & \\
\hline
\end{tabular}

Tablo 7 incelendiğinde öğretmenlerin mesleki yeterlilik algılarının ilerlemecilik, varoluşçuluk, yeniden kurmacılık ve daimicilik tarafında yordanmasını açıklamak için kurulan modelin anlamlı olduğu görülmektedir $(\mathrm{F}(4,274)=17,595 ; \mathrm{p}<.01)$. Bunun ardından öğretmenlerin mesleki yeterlilik algılarının eğitim inançları tarafından ne düzeyde yordandığını belirlemek amacıyla yapılan çoklu doğrusal regresyon analizinin bulguları Tablo 8' de verilmiştir.

Tablo 8. Öğretmenlerin Mesleki Yeterlilik Algılarının Eğitim İnançları Tarafında Yordanmasına İlişkin Regresyon Analizinin Sonuçları

\begin{tabular}{lccccccc}
\hline Yordayan Değişkenler & $\boldsymbol{B}$ & Std. Hata & $\boldsymbol{\beta}$ & $\boldsymbol{t}$ & $\boldsymbol{p}$ & $\dot{\text { Ikili } \boldsymbol{r}}$ & Kismi $\boldsymbol{r}$ \\
\hline (Sabit) & 12,620 & 3,828 & & 3,297 &, $00^{*}$ & & \\
\hline İlerlemecilik &, 277 &, 151 &, 253 & 2,891 &, $00^{*}$ & 0,441 & 0,161 \\
\hline Varoluşçuluk &, 234 &, 254 &, 245 & 2,986 &, $00^{*}$ & 0,438 & 0,166 \\
\hline Yeniden Kurmacllık &, 137 &, 195 &,- 164 & $-2,300$ &, $02^{*}$ & 0,227 & $-0,129$ \\
\hline Daimicilik &, 043 &, 159 &, 165 & 2,399 &, $01^{*}$ & 0,315 & 0,134 \\
\hline
\end{tabular}

$\mathrm{R}=, 452 ; \mathrm{R} 2=, 204 ; \mathrm{F}(4,274)=17,595 ; \mathrm{p}<.01$

Analize göre regresyon modelinin anlamlı olduğu belirlenmiş $(F(4,274)=17,595 ; p<.01)$ ve modelde ilerlemecilik eğitim inancının mesleki yeterlilik algısını en yüksek düzeyde yordayan boyut olduğu belirlenmiştir $(\beta=.254)$. Bu dört eğitim inancı birlikte öğretmenlerin mesleki yeterlilik algısındaki değişimin \%20'sini açılamaktadır. Regresyon modelinde ilerlemecilik eğitim inancını takiben varoluşçuluk $(\beta=.234)$, yeniden kurmacılık $(\beta=.137)$ ve daimicilik eğitim inançları $(\beta=.043)$ da mesleki yeterlilik algısını anlamlı olarak yordamaktadır. Bulgulara göre öğretmenlerin mesleki yeterlilik algılarının yordanmasına ilişkin regresyon denklemi şu şekilde oluşmuştur;

Mesleki Yeterlilik Algısı $=12,620+0,254$ * İlerlemecilik $+0,234$ * Varoluşçuluk + 0,137 *

Yeniden Kurmac1lı $+0,043 *$ Daimicilik 


\section{Tartışma}

Eğitim olgusu ve içerisinde barındırdığı bütün unsurlar, değişim ve gelişim temelinde ilerler. Eğitime pek çok olgu veya olay yön vermiş ve değişimler yaratmıştır. Örneğin Sanayi Devrimi'nin etkilediği önemli bir olgu eğitimdir. Sanayi Devrimi öncesinde eğitimin temelinde yer alan usta çırak ilişkisi artık istenileni veremeyeceğinden endüstriyel okul modelleri ortaya çıkmıştır (Saykılı, 2018). Bu durum eğitimin bütün uygulama ve süreçlerini derinden etkilemiştir. Bununla beraber dijitalleşen dünyaya ve gereksinimlerine ayak uydurmak için eğitim olgusu ve paradigmaları farklılaşmıştır. Öğrencileri topluma ve devletin işleyen çarkına hazırlamak için pek çok eğitim felsefesi denenmiştir. $\mathrm{Bu}$ araştırma ile öğretmenlerin eğitim felsefeleri belirlenerek bu eğitim inançlarının mesleki yeterlilik algılarını nasıl etkilediği gösterilmeye çalışılmıştır.

Araştırmanın ilk probleminde öğretmenlerin eğitim inançlarının ve mesleki yeterlilik inançlarının ne düzeyde olduğu saptanmıştır. Elde edilen bulgulara bakıldığında öğretmenlerin eğitim inançlarından en çok varoluşçuluk eğitim inancına katılım gösterdikleri görülmektedir. Varoluşçuluk eğitim felsefesinin temelinde insan ve insan iradesi vardır. Eğitimde ise varoluş̧̧uluk öğrencinin kendi öğretim yaşantısını kendisinin seçmesi ve bundan sorumlu olmasıdır (Sönmez, 1994). Öğretmenlerin varoluşçuluk felsefesini daha çok benimsemesinin alt metninde eğitimin artık öğrenciye görelik ilkesine dayanarak öğrencinin aktif olduğu öğrenme koşullarında eğitilmeye başlamasının etkisi büyüktür. Öğretmen rehber öğrenci ise keşfeden ve yapılandıran konumuna geçmiştir. Ayrıca öğretmenlerin, öğrencilerin öğrenme farklılıkları hususunda esnekliğe ve seçime imkân tanıması nedeniyle de bu eğitim felsefesini benimsediği söylenebilir. Aslan'ın (2017) sınıf öğretmenlerinin eğitim inançlarını belirlemeye yönelik yaptığı çalışmasında öğretmenlerin en çok varoluşçu eğitim felsefesine yatkın olduğu, en az benimsenen eğitim felsefesinin ise esasicilik olduğu saptanmıştır. Bu sonuçlar araştırmanın bulguları ile örtüşmektedir. Yine Hayırsever ve Oğuz'un (2017) öğretmen adayları ile yaptı̆̆ı çalışmada da öğretmen adaylarının en çok benimsediği eğitim felsefesinin varoluşçu eğitim felsefesi olduğu görülmüştür. Diğer yandan ise öğretmenlerin varoluşçuluk eğitim felsefesinden sonra sırasıyla daimicilik, ilerlemecilik, yeniden kurmacılık ve esasicilik eğitim felsefelerini benimsedikleri görülmüştür. Öğretmenlerin daimicilik esasına dayanan bir eğitimden geçmeleri, daimiciliğin entelektüel insan yetiştirme amacı ve değerler eğitimine önem vermesi gibi sebeplerden bu eğitim felsefelerini benimsedikleri söylenebilir. En az benimsenen inanç ise esasicilik eğitim felsefesidir. Bu eğitim felsefesinin temelinde ödül-ceza kavramlarının yer alması öğretmeni otoriter güç olarak göstermesi öğretmenlerin bu eğitim felsefesini benimsememesine yol açmıştır. Araştırmanın sonuçları alanyazında bu konuyla ilgili yapılan çalışmaların sonuçlarıyla da uyumludur (Alkın-Şahin, Tunca ve Ulubey, 2014; Aslan, 2017; Eğmir ve Çelik, 2019; Ekiz, 2005; Uğur ve Çalmaşur, 2017; Yılmaz ve Tosun, 2013). Buna karşın Tekin ve Üstün (2008) yaptıkları 
çalışmalarında en az benimsenen eğitim felsefelerini varoluşçuluk ve idealizm olarak belirlemiştir. Bu sonuçlar ise bu araştırmadan elde edilen sonuçlarla örtüşmemektedir. Bunun nedeni geçen zaman ve değişen eğitimsel olguların öğretmenlerin eğitim anlayışlarını da değiştirmesi olabilir.

Araştırmanın ikinci probleminde öğretmenlerin eğitim inançları ve mesleki yeterlilik algılarının cinsiyet, mesleki kıdem ve görev yapılan kademe değişkenlerine göre anlamlı olarak farklılaşıp farklılaşmadığı incelenmiştir. Elde edilen bulgular ışığında mesleki yeterlilik algısının cinsiyet açısından anlamlı bir farklılık göstermediği görülmüştür. Kadın ve erkek öğretmenlerin öğretmenlik mesleğine ilişkin yeterlilik algılarının yüksek olduğu görülmüştür. Öğretmenlerin eğitim inançlarının incelenmesi sonucunda erkek öğretmenlerin esasicilik felsefesini kadın öğretmenlerden daha fazla benimsediği belirlenmiştir. Kadın öğretmenler çağdaş eğitim felsefelerini daha çok benimserken, erkek öğretmenlerin geleneksel felsefelere daha yatkın oldukları saptanmıştır. Bu bulgular Biçer, Er ve Özel'in (2013) araştırma bulguları ile benzerlik göstermektedir. Kadın öğretmenlerin 'esasicilik' ve 'daimicilik' dışında kalan eğitim inançlarından daha yüksek puan aldıkları görülmüştür. Eğmir ve Çelik'in (2019) araştırması da bu bulguları desteklemektedir. Nitekim söz konusu araştırmada erkek öğretmenler daha otoriter ve baskı yönelimli bir eğitim sürecini benimsediklerini belirtmişlerdir. Duman ve Ulubey'in (2008) çalışmasında erkeklerin \%23,9'u geleneksel eğitim inançlarını benimserken kadınlarda bu oran \%19,3 olarak belirlenmiştir. Buna karşın Bingöl ve Kinay'ın (2018) çalışmalarında benimsenen eğitim felsefesinin cinsiyete göre anlamlı olarak değişmediği belirlenmiştir.

Çalışmada ayrıca öğretmenlerin eğitim inançları ve mesleki yeterlilik algılarının mesleki kıdemlerine göre farklılaşıp farklılaşmadığı incelenmiştir. Elde edilen bulgulara göre öğretmenlerin yeniden kurmacılık eğitim inancı dışında diğer eğitim inançlarında ve mesleki yeterlilik algılarında mesleki kıdeme göre anlamlı bir farklılaşma görülmüştür. Özellikle mesleğe yeni başlayan öğretmenlerin çağdaş eğitim anlayışlarına daha yatkın oldukları bulgular ile desteklenmiştir. Daha yüksek mesleki kıdeme sahip öğretmenler ise daha çok geleneksel eğitim anlayışlarına sahiptir. Özellikle 2005-2006 eğitim öğretim yılından sonra yeni bir eğitim anlayışı olan yapılandırmacı eğitim anlayışına geçilmiş ve bu anlayışın temeli olan ilerlemecilik eğitim felsefesi öğretmenler tarafından benimsenmeye başlanmıştır (Aslan, 2017). Daha önce mesleğe başlayan öğretmenlerin bu yeni anlayışla sonradan tanışmaları, öğrendikleri ve uyguladıkları davranışçı anlayıştan kopmaya direnç göstermelerine neden olmuştur. Göreve yeni başlayan öğretmenler ise bu eğitim anlayışlarına daha çabuk adapte olmakta ve özümsemektedirler. Zira eğitim fakültelerinden bu anlayışların temellerini zihinlerinde atarak mezun olmaları beklenmekte ve buna yönelik öğretmen yetiştirme programları hazırlanmaktadır. Bu yetiştirme programlarında öğretmen adaylarının çağdaş eğitim anlayışlarına sahip olmaları, bu anlayışlara uygun öğretim yöntem ve teknikleri öğrenmeleri ve geliştirmeleri 
amaçlanmıştır (Işık, Çiltaş ve Baş, 2010). Bu yüzden yeni nesil öğretmenler her anlamda çağdaş eğitim anlayışlarını özümseyerek göreve başlamakta, eski nesil öğretmenler ise davranışçı yaklaşımın gölgesinde çağdaş eğitim anlayışlarını öğrenmekte ve uygulamaktadır. Bu sebeple eski nesil öğretmenlerin geleneksel eğitim anlayışlarını daha çok benimsedikleri söylenebilir. Bununla birlikte belli bir mesleki kıdeme sahip öğretmenlerin daha kontrollü, daha sakin ve programa daha bağlı olduklarını da söylemek mümkündür (Aslan, 2017). Bu yüzden öğretmen merkezli, konu ağırlıklı olan geleneksel eğitim felsefelerini benimsedikleri görülmektedir. Çalışmanın bulgularına paralel olarak Aslan (2017) çalışmasında, mesleki kıdemi yüksek olan öğretmenlerin daha çok geleneksel eğitim anlayışlarına sahip olduklarını belirtmiştir. Oğuz, Altınkurt, Yılmaz ve Hatipoğlu (2014) çalışmalarında benzer bulgular elde etmiştir. Ayrıca öğretmenlerin eğitim inançlarının ele alındığı makale ve tezleri inceleyen Eğmir (2019) çalışmasında öğretmenlerinin kıdemleri arttıkça geleneksel eğitim felsefelerini daha fazla benimsediklerini saptamıştır.

Çalışmada öğretmenlerin eğitim inançları ve mesleki yeterlilik algılarının görev yapılan kademe değişkenine göre anlamlı olarak farklılaşıp farklılaşmadığı incelenmiştir. Elde edilen bulgular öğretmenlerin eğitim inançlarının kademe yükseldikçe geleneksele kaydığını, temel eğitim öğretmenlerinin çağdaş eğitim felsefelerini daha çok benimsediğini göstermiştir. Bu durum temel eğitim kademesinin, çocukların keşfetme meraklarının yoğun olduğu bir dönem olmasından ve çağdaş eğitim felsefelerinin gereklerini ve anlayışını uygulamaya daha müsait olmasından da kaynaklanmaktadır. Bu bulgulara paralel olarak Eğmir (2019) çalışmasında okulöncesi öğretmenlerinin branşlarının yapısı gereği çağdaş eğitim felsefelerini benimsediklerini; buna karşın özellikle ortaokul ve lise kademelerinde görev yapan öğretmenlerin, ders yoğunluğunun artmasıyla ve disiplin temelli uzmanlaşma anlayışının gereği geleneksel eğitim felsefelerini benimsediklerini belirlemiştir. Ortaöğretimde disiplin tasarımı nedeniyle bilgi aktarımının yoğun olması, öğrencilerin ve öğretmenlerin sınav odaklı olması gibi nedenler çağdaş eğitim felsefeleri yerine geleneksel eğitim felsefeleri benimsenmiştir. Mesleki yeterlilik algısına bakıldığında eğitim inançlarıyla paralel bir bulgu elde edilmiştir. Çağdaş eğitim felsefelerini benimseyen öğretmenlerin mesleki yeterlilik algıları daha yüksek çıkmıştır. Bunun sebebi çağdaş eğitim felsefelerinin temelinde araştıran ve kendini geliştiren öğretmen modeli yatmaktadır. Cevizci (2018) öğretmenin iyi bir gözlemci ve öğrenmeyi kolaylaştırıcı özelliklerinin bulunması gerektiğini, öğretmenin öğrenme sürecine rehberlik ederken geleneksel öğretmen tipine göre sorumluluğunun daha fazla olduğunu belirtmiştir. Dewey (1938) ise öğretmenin olgun ve deneyim sahibi olması gerektiğini ifade etmiştir. Geleneksel eğitim felsefelerinde otoriter güç öğretmendir ve öğretmen keşfedilmiş bilgiyi aktarır. Bu yüzden öğretmen araştırmacı değil eğitici ya da öğreticidir (Cevizci, 2018). 
Çalışmada ayrıca öğretmenlerin eğitim inançlarıyla mesleki yeterlilik algıları arasında ilişki olup olmadığı incelenmiştir. Yapılan analizler sonucunda öğretmenlerin 'esasicilik' alt boyutu dışında diğer alt boyutları ile mesleki yeterlilik algıları arasında pozitif bir ilişki bulunmuştur. En yüksek ilişki ise 'ilerlemecilik' eğitim anlayışı iledir. Mesleki yeterlilik algılarının yüksek olmasının aktif öğrenen ve öğreten öğretmen anlayışını benimseyen eğitim felsefelerinin etkisi oldukça fazladır. İlerlemecilik çağdaş eğitim felsefelerinden olması ve öğretmenin öğrencilerin aktif öğrenecekleri öğrenme ortamları ve yaşantıları hazırlamasının öğretmeni daha çok araştırmaya, gelişim göstermeye itmektedir. Bu durum ise mesleki yeterlilik düzeyinin artmasını sağlamaktadır (Dewey, 1938). Balcı ve Küçükoğlu (2019) araştırmalarında ilerlemecilik ve varoluşçuluk eğitim felsefelerini benimseyen okul öncesi öğretmen ve öğretmen adaylarının özyeterlilik algılarının daha yüksek olduğunu saptamışlardır. Bu sonuç ise elde edilen veriler ile paralellik göstermektedir. Ayrıca Anderson, Greene ve Loewen (1988) çalışmalarında yeterlilik düzeyi yüksek öğretmenlerin daha çok pragmatist eğitim felsefelerini benimsediklerini belirlemişlerdir.

\section{Sonuç}

$\mathrm{Bu}$ çalışmada öğretmenlerin eğitim inançlarıyla mesleki yeterlilik düzeyleri arasındaki ilişki incelenmiştir. Elde edilen bulgular doğrultusunda öğretmenlerin eğitim felsefelerinden en çok 'varoluşçuluk' en az ise 'esasicilik' eğitim felsefesini benimsediği ortaya çıkmıştır. Özellikle göreve yeni başlayan ve kademe olarak temel eğitimde görev alan öğretmenlerin daha çağdaş eğitim felsefelerine yöneldikleri ve mesleki yeterlilik algılarının daha yüksek olduğu belirlenmiştir. Kıdem olarak daha fazla çalışmış öğretmenlerin ve kademe olarak orta öğretimde görev alan öğretmenlerin ise daha çok geleneksel eğitim felsefelerine yönelirken mesleki yeterlilik algılarının da düşük olduğu saptanmıştır. Ayrıca kadın öğretmenlerin erkek öğretmenlere göre çağdaş eğitim felsefelerini daha fazla benimsedikleri görülmüştür. Mesleki yeterlilik algı puanları kadın öğretmenlerin lehine çıksa da fark anlamlı değildir. Bu durumda benimsenen eğitim felsefesinin mesleki yeterlilik algılarını önemli derecede etkilediğini ve bu iki durum arasında doğrusal bir ilişki olduğu çalışmanın verileri ile desteklenmiştir. Yani öğretmenlerin çağdaş eğitim felsefelerini benimsemeleri; Dewey (1938) ve Cevizci'nin (2018) de belirttiği gibi öğrenciler için öğrenme yaşantısı oluşturmak, öğrenme sürecine rehberlik etmek öğretmenlerin sorumluluğunu arttırdığından ve daha çok deneyim gerektirdiğinden, öğretmenlerin aktif, öğrenen ve gelişime açık olmalarını gerektirir. Bu durum öğretmenlerin mesleki anlamda kendilerini daha yeterli algılamalarını sağlamaktadır.

Bu çalışmada öğretmenlerin eğitim inançlarının ve mesleki yeterlilik algılarının ne düzeyde olduğu ve bu iki olgu arasındaki ilişkinin düzeyi incelenmiştir. Bu iki olgu derinlemesine bir bakış elde edilmesi amacıyla nitel yöntemlerle de çalışılabilir. Bununla birlikte öğretmenlerin mesleki yeterlilik algılarını geliştirecek müdahale programlarının eylem araştırması yoluyla çalışılması da 
önemli bir katkı yapacaktır. Öğretmenlerin hem eğitim inançlarını hem de mesleki yeterlilik algılarını yordayan değişkenlerin yapısal eşitlik modellemesi çalışmalarıyla incelenmesi de yine bu iki olguya ilişkin bağlamı belli bir düzeye ulaştırmada yardımcı olacaktır.

\section{Kaynaklar}

Alkın-Şahin, S., Tunca, N., \& Ulubey, Ö. (2014). Öğretmen adaylarının eğitim inançları ile eleştirel düşünme eğilimleri arasındaki ilişki. İlköğretim Online, 13(4), 1473-1492.

Altınkurt Y., Yılmaz, K., \& Oğuz, A. (2012). İlköğretim ve ortaöğretim okulu öğretmenlerinin eğitim inançları. Ondokuz Mayıs Üniversitesi Ĕ̆itim Fakültesi Dergisi, 31(2), 1-19.

Anderson, R. N., Greene, M. L., \& Loewen, P. S. (1988). Relationships among teachers' and students' thinking skills, sense of efficacy, and student achievement. Alberta Journal of Educational Research, 34(2), 148-165.

Aslan, S. (2017). Sınıf öğretmenlerinin eğitim inançlarının çeşitli değişkenler açısından incelenmesi. Kastamonu Eğitim Dergisi, 25(4), 1453-1468.

Avcı-Akçalı, A. (2016). Tarih öğretmen adaylarının mesleki yeterlik algıları: Karşılaştırmalı bir araştırma. Eğitim ve Öğretim Araştırmaları Dergisi, 5(4), 240-249.

Ayçiçek, B., \& Yelken, T. Y. (2019). The investigation of teachers' educational beliefs and attitudes towards democracy and multicultural education according to various variables. International Journal of Academic Research in Education, 4(1-2), 41-56.

Balcı, A., \& Küçükoğlu, A. (2019). Okul öncesi öğretmen ve öğretmen adaylarının eğitim inançları ve özyeterlik inançları üzerine bir inceleme. Kastamonu Education Journal, 27(3), 1123-1139.

Bandura, A. (1994). Self-efficacy. New York: Academic Press.

Baş, G. (2015). Öğretmenlerin eğitim felsefesi inançları ile öğretme-öğrenme anlayışları arasındaki ilişki. Eğitim ve Bilim, 40(182), 111-126.

Biçer, B., Er, H., \& Özel, A. (2013). Öğretmen adaylarının epistemolojik inançları ve benimsedikleri eğitim felsefeleri arasındaki ilişki. Ĕ̆itimde Kuram ve Uygulama, 9(3), 229-242.

Bingöl, U., \& Kinay, İ. (2018). Türkçe öğretmen adaylarının benimsedikleri eğitim felsefelerinin çeşitli değişkenlere göre değerlendirilmesi (Ziya Gökalp Eğitim Fakültesi Örneği). Elektronik Sosyal Bilimler Dergisi, 17(68), 1636-1647.

Büyüköztürk, Ş. (2014). Sosyal bilimler için veri analizi el kitabı (18. baskı). Ankara: Pegem Akademi.

Büyüköztürk, Ş., Kılıç-Çakmak, E., Akgün, Ö. E., Karadeniz, Ş., \& Demirel, F. (2013). Bilimsel araştırma yöntemleri. (15. bask1). Ankara: Pegem Akademi.

Cevizci, A. (2018). Felsefe. Eskişehir: Eskişehir Üniversitesi. 
Çapri, B., \& Çelikkaleli, Ö. (2008). Öğretmen adaylarının öğretmenliğe ilişkin tutum ve mesleki yeterlik inançlarının cinsiyet, program ve fakültelerine göre incelenmesi. İnönü Üniversitesi Eğitim Fakültesi Dergisi, 9(15), 33-53.

Çelik, R., \& Orçan, F. (2016). Öğretmen adaylarının eğitim inançları üzerine bir çalışma. Eğitimde Kuram ve Uygulama, 12(1), 63-77.

Dewey, J. (1938). Experience and education. New York: Kappa Delta Pi.

Duman, B., \& Ulubey, Ö. (2008). Öğretmen adaylarının benimsedikleri eğitim felsefelerinin öğretim teknolojilerini ve interneti kullanma düzeylerine etkisi ile ilgili görüşleri. Muğgla Üniversitesi Sosyal Bilimler Enstitüsü Dergisi, 20, 95-114.

Eğmir, E. (2019). Eğitim inançlarına ilişkin Türkiye'de yapılmış çalışmaların analizi: öğretmen ve öğretmen adaylarına ilişkin bir inceleme. Pesa Uluslararası Sosyal Araştırmalar Dergisi, 5(3), 264278. https://doi.org/10.25272/j.2149-8385.2019.5.3.05

Eğmir, E., \& Çelik, S. (2019). The educational beliefs of pre-service teachers as an important predictor of teacher identity. International Journal of Contemporary Educational Research, 6(2), 438-451. https://doi.org/10.33200/ijcer.621717

Ekiz, D. (2005). Sınıf öğretmeni adaylarının eğitim felsefesi akımlarına ilişkin eğilimlerinin karşılaştırılması. Ondokuz Mayıs Üniversitesi Eğitim Fakültesi Dergisi, 19, 1-11.

Epçaçan, C. (2016). Eğitimin felsefi temelleri. A. Arslan (Ed.), Eğitim bilimine giriş içinde. (s. 119-144). Ankara: Nobel.

Erişen, Y. (2019). Eğitimin felsefi temelleri. E. Karip (Ed.), Eğitime giriş içinde (s. 200-223) Ankara: Pegem.

Gutek, G. L. (1997). Eğitime felsefi ve ideolojik yaklaşımlar. (N. Kale, Çev.). Ankara: Pegem.

Hayırsever, F., \& Oğuz, E. (2017). Öğretmen adaylarının eğitim inançlarının eleştirel düşünme eğilimlerine etkisi. Abant İzzet Baysal Üniversitesi Ĕ̆itim Fakültesi Dergisi, 17(2), 757-778.

Işık, A., Çiltaş, A., \& Baş, F. (2010). Öğretmen yetiştirme ve öğretmenlik mesleği, Atatürk Üniversitesi Sosyal Bilimler Enstitüsü Dergisi, 14(1), 53-62.

Karacaoğlu, D. (2008). Öğretmenlerin yeterlilik algıları. Yüzüncü Yll Üniversitesi Eğitim Fakültesi Dergisi, 5(1), 70-97.

Kılıç, S. (2013). Örnekleme yöntemleri. Journal of Mood Disorders, 3(1), 44-46.

Mertens, D. M. (2015). Research and evaluation in education and psychology (4. Baskı). Los Angeles: Sage.

Oğuz, A., Altınkurt, Y., Yılmaz, K., \& Hatipoğlu, S. (2014). Öğretmenlerin eğitim inançları ile öğrenen özerkliğini destekleme davranışları arasındaki ilişki. Turkish Journal of Educational Studies, 1(1), 37-78. 
Sarp-Astan, G. (2017). Müzik öğretmeni adaylarının mesleki yeterlik ve öz-yeterlik algılarının belirlenmesi. (Yüksek lisans tezi). http://docs.neu.edu.tr/library/6585862400.pdf sayfasından erişilmiştir.

Saykılı, A. (2018). Dünden yarına eğitim paradigmaları: Sanayi modeli eğitim dijital çağda yeterli mi? Açıköğretim Uygulamaları ve Araştırmaları Dergisi, 4(2), 189-198.

Schwarzer, R., Schmitz, G. S., \& Daytner, G. T. (1999). Teacher self efficacy. www.fuberlin.de./gesund/skale/Language Selection Turkish sayfasından erişilmiştir.

Sönmez, V. (1994). Eğitim felsefesi. Ankara: Anı Yayıncılık.

Şişman, M. (2006). Eğitim bilimine giriş. Ankara: Pegem A Yayıncılık.

Tavşancıl, E. (2006). Tutumların ölçülmesi ve SPSS ile veri analizi (3. Baskı). Ankara: Nobel Yayın.

Tekin, S., \& Üstün, A. (2008). Amasya eğitim fakültesi öğretmen adaylarının eğitim süreci hakkındaki felsefi tercihlerinin tespiti. Selçuk Üniversitesi Ahmet Keleşoğlu Ĕ̆itim Fakültesi Dergisi, 25, 145158.

Tunca, N., Alkın-Şahin, S., \& Oğuz, A. (2015). Öğretmenlerin eğitim inançları ile meslekî değerleri arasındaki ilişki. Kalem Eğitim ve İnsan Bilimleri Dergisi, 5(1), 11-47.

Tuncel, G. (2004). Öğretmenlerin kendi eğitim felsefelerini inşa etmeleri üzerine. Kazım Karabekir Eğitim Fakültesi Dergisi, 10, 223-242.

Turan, E. Z. (2016). Eğitimin felsefi temelleri. A. Uzunöz (Ed.). Ĕ̆itim bilimine giriş içinde (s. 125-150). Ankara: Pegem Akademi.

Uğurlu, C. T., \& Çalmaşur, H. (2017). Öğretmenlerin ve öğretmen adaylarının eğitim inançlarına ilişkin görüşleri: bir karma yöntem çalışması. Adıyaman Üniversitesi Sosyal Bilimler Enstitüsü Dergisi, 9(25), 230-273.

Yaralı, D. (2020). Öğretmen adaylarının eğitim inançlarının çeşitli değişkenler açısından incelenmesi (Kafkas Üniversitesi Örneği). Bayburt Eğitim Fakültesi Dergisi, 15(29), 160-185.

Yılmaz, K., \& Tosun, M. F. (2013). Öğretmenlerin eğitim inançları ile öğretmen öğrenci ilişkilerine yönelik görüşleri arasındaki ilişki, Eğitim ve Öğretim Araştırmaları Dergisi, 2(4), 205-218.

Yılmaz, K., Altınkurt, Y., \& Çokluk, Ö. (2011). Eğitim İnançları Ölçeği'nin geliştirilmesi: Geçerlik ve güvenirlik çalışması. Kuram ve Uygulamada Eğitim Bilimleri, 11(1), 335-350.

\section{Extended Summary}

Philosophy is one of the most important factors affecting the phenomenon of education today. Philosophy has been associated with many sciences and even paved the way for the formation of many positive sciences. Its relationship with education is in the form of a close and complementary spiral. The reason for this is that both education and philosophy study human-being. Sönmez (1994), states that every economic, social, and political system is based on a philosophy. Since education is 
one of these systems, the dominant philosophy in society also affects educational understanding, preferences, and actions. It can be stated that the most basic component among the stakeholders specified for the functioning of an education system is teachers. For this reason, the behaviors of teachers and the belief systems underlying these behaviors are very important. According to Bandura (1994), one of the most important factors influencing the emergence of behaviors is the individual's accepted beliefs. From this point of view, it is predicted that the educational beliefs of the teachers, who are the implementers of education, will be reflected in their educational practices.

What kind of people the states want to raise is directly related to the educational philosophies they guide. There are four educational philosophies that guide education in general; perennialism, essentialism, progressivism, and re-constructionism. Among these educational philosophies, perennialism and essentialism are traditional; progressivism and re-constructionism are known as contemporary educational philosophies. Perennialism and essentialism, which are traditional educational philosophies, continued their influence for many years and the behaviorist approach overlapped with these two philosophies. In our country, with the revision of the programs in 2005, the behaviorist approach was shifted to the constructivist approach. It can be said that the basis of the constructivist approach is the progressive and reconstructive educational philosophies.

Teachers are the most important professional group that should embrace and reflect change and development. According to the developing world and technology conditions, the qualifications expected from teachers have increased and changed. According to Karacaoğlu (2008), the quality of teachers directly affects the quality of students. According to Sarp-Astan (2017), increasing the quality of teachers depends on their self-efficacy perceptions and professional competencies. Bandura (1994) stated that perceptions of competence are formed by the knowledge, skills, and experiences of individuals. In this respect, self-efficacy and professional competence perceptions are formed as a result of teachers' experiences in the learning-teaching processes.

In the light of this information, it was first aimed to determine what the teachers' dominant educational beliefs are and what their professional competence perceptions are. Secondly, it was aimed to determine whether teachers' educational beliefs and perceptions of professional competence differ significantly according to gender, professional seniority, and level of duty. Finally, it was investigated whether there is a significant relationship between teachers' educational beliefs and professional competence perceptions and to what extent teachers' educational beliefs predict their professional competence perceptions. The study was designed according to the relational survey model. The data collection tools of the research were applied to 279 teachers working at different levels in the province of Afyonkarahisar, which was determined by the appropriate sampling method. The Scale of Educational Beliefs developed by Yilmaz, Altinkurt, and Çokluk (2011) and the Teacher 
Self-proficiency Perception Scale developed by Schwarzer, Schmitz, and Daytner (1999) were used to collect data during the research process.

When the findings are examined, it is seen that the teachers mostly participate in the existential education belief among their educational beliefs. The fact that education is now based on the principle of relevance to the student in learning conditions in which the student is active has a great impact on the teachers' adoption of the philosophy of existentialism. On the other hand, it was observed that teachers adopted perennialism, progressivism, re-constructionism, and essentialism education philosophies, sequentially, after existentialism education philosophy. It can be said that teachers have adopted perennialism educational philosophies due to the fact that they have undergone an education based on perennialism, the purpose of perennialism is to raise intellectual people, and it gives importance to values education. The least adopted belief is the essentialist educational philosophy. The fact that the concepts of reward and punishment are at the base of this educational philosophy, showing the teacher as an authoritarian power, has led to the teachers not adopting this educational philosophy.

In the light of the findings, it was seen that the perception of professional competence did not show a significant difference in terms of gender. Also, it was determined that male teachers adopted the philosophy of essentialism more than female teachers. It has been determined that while female teachers adopt contemporary educational philosophies more, male teachers are more inclined to traditional philosophies. According to the findings, there was a significant difference in terms of professional seniority in teachers' educational beliefs and perceptions of professional competence apart from the belief in reconstructive education. It has been supported by the findings that teachers who are new to the profession are more inclined to contemporary education understandings. Teachers with higher professional seniority, on the other hand, have more traditional education understandings. When the professional competence perceptions of the teachers are examined, it is seen that there is a difference between the teachers with 1-5 years of professional seniority and those with 6-10 years in favor of teachers with 1-5 years of experience.

Besides, the findings showed that the educational beliefs of the teachers shifted to the traditional as the level increased, and the basic education teachers adopted the contemporary educational philosophies more. This situation is also due to the fact that the basic education level is a period when children's curiosity to explore is intense, and it is more suitable for applying the requirements and understanding of contemporary educational philosophies. Considering the perception of professional competence, a parallel finding was obtained with educational beliefs. Teachers who adopt contemporary educational philosophies have higher perceptions of professional 
competence. The reason for this is the model of the teacher who researches and develops himself on the basis of contemporary educational philosophies.

The study also examined whether there is a relationship between teachers' educational beliefs and their perceptions of professional competence. As a result, a positive relationship was found between the teachers' sub-dimensions other than the 'essentialism' sub-dimension and their perceptions of professional competence. The highest relationship is with the understanding of 'progressivism' education. As a result of the multiple linear regression analysis conducted to determine to what extent teachers' perceptions of professional competence are predicted by their educational beliefs, these four educational beliefs together explain $20 \%$ of the change in teachers' perceptions of professional competence. According to the analysis, it was determined that progressive education belief in the model was the dimension that predicted the perception of professional competence at the highest level.

\section{Araştırmacıların Katkı Oranı Beyanı}

Bu araştırmaya; birinci yazar \% 40, ikinci ve üçüncü yazar \% 30 oranında katkı sağlamıştır.

\section{Destek ve Teşekkür Beyanı}

$\mathrm{Bu}$ araştırmada herhangi bir kurum, kuruluş ya da kişiden destek alınmamıştır.

\section{Çatışma Beyanı}

Araştırmacıların araştırma ile ilgili diğer kişi ve kurumlarla herhangi bir kişisel ve finansal çıkar çatışması yoktur.

\section{Etik Kurul Beyanı}

$\mathrm{Bu}$ araştırma, Afyon Kocatepe Üniversitesi Sosyal ve Beşeri Bilimler Bilimsel Araştırma ve Yayın Etiği Kurulunun 22.01.2021 tarih ve 2021/38 sayılı onayı ile yürütülmüştür. 